\title{
A PRELIMINARY ASSESSMENT OF THE SOURCE OF OESTROGEN WITHIN THE OVARY OF THE DOMESTIC FOWL, GALLUS DOMESTICUS
}

\author{
B. E. SENIOR AND B. J. A. FURR* \\ Department of Physiology, National Institute for Research in Dairying, \\ Shinfield, Reading, Berkshire RG2 $9 A T$
}

(Received 15th August 1974)

\begin{abstract}
Summary. Oestradiol was measured by radioimmunoassay in blood draining individual preovulatory follicles and in different ovarian tissues of the hen. The concentration of oestradiol in blood from follicles 20 to $50 \mathrm{hr}$ before ovulation ranged from 66 to $264 \mathrm{pg} / \mathrm{ml}$ and was less than that in peripheral blood collected concurrently, suggesting a net uptake rather than secretion of oestradiol by the follicle at these times.

In one bird approximately $6 \mathrm{hr}$ before ovulation, the highest content of oestradiol in tissue ( $35 \mathrm{ng}$ ) was in the small $(<5 \mathrm{~mm})$ follicles and ovarian stroma; this represented $87.5 \%$ of the total ovarian content. Only 0.86 to $1.02 \mathrm{ng}$ oestradiol $(2.0$ to $2.5 \%)$ was found in the large preovulatory follicles and $2.22 \mathrm{ng}(5.5 \%)$ in the postovulatory follicles. High concentrations of oestradiol $(2.4 \mathrm{ng} / \mathrm{g})$ were also found in the liver.

These results suggest that the small follicles and/or ovarian stroma are the main site of oestradiol production in the fowl; they do not exclude the possibility that oestradiol is secreted at a high rate by the mature follicle for a short period immediately before ovulation, thus influencing the release of $\mathrm{LH}$.
\end{abstract}

\section{INTRODUCTION}

In the domestic fowl, progesterone may be the ovarian hormone that causes the release of LH required for ovulation (Fraps \& Dury, 1943; Fraps, 1955, 1961; Ralph \& Fraps, 1959, 1960; Furr, 1969, 1973; Peterson \& Common, 1971; Kappauf \& van Tienhoven, 1972; Furr, Bonney, England \& Cunningham, 1973) though, in mammals, oestrogens may induce the LH surge (Vande Wiele \& co-authors, 1970). A similar rôle for oestrogens in the hen has not been fully investigated. During the ovulatory cycle of the hen, maximum concentrations of oestrone and oestradiol are known to occur in peripheral plasma 4 to $6 \mathrm{hr}$ before ovulation (Peterson \& Common, 1972; Senior, 1974a) and the increase in the concentration of oestradiol precedes that of LH by $2 \mathrm{hr}$ (Senior \& Cunningham, 1974). If this preovulatory oestrogen peak is involved in the mechanism of ovulation, it might result from an increase in the rate of steroidogenesis in the preovulatory follicle similar to that which occurs in mammalian

* Present address: Imperial Chemical Industries Limited, Pharmaceuticals Division, Mereside Alderley Park, Macclesfield, Cheshire SK10 4TG. 
species. The purpose of the present work was to determine the site of oestrogen secretion within the hen ovary by studying the concentration of oestradiol in blood draining individual follicles and by estimating the levels of oestradiol in different ovarian tissue elements.

\section{MATERIALS AND METHODS}

\section{Solvents and reagents}

The organic solvents and reagents used for oestradiol radioimmunoassy are described by Glencross, Munro, Senior \& Pope (1973).

\section{Experimental birds}

White Leghorn laying hens were caged singly, subjected to a 14-hr light/10-hr dark regimen and fed on a commercial layers' ration.

\section{Collection of follicular venous blood}

A polyvinyl cannula was inserted (Furr, 1973) into individual follicles of five anaesthetized laying hens. Heparin (2000 U) in $2 \mathrm{ml}$ of $0.9 \%$ sodium chloride solution was injected through a brachial vein cannula to prevent blood clotting during collection. Follicular vein blood samples were collected over 10-min intervals $(0.5$ to $1.0 \mathrm{ml}$ blood/sample). During this collection, a sample of peripheral blood was withdrawn from the brachial vein cannula. In one bird (F2), $1 \mu \mathrm{g}$ ovine LH (NIH-LH-S11) was injected into the brachial vein during collection of follicular blood.

At the end of the experiment, the hens were killed and the ovaries examined. From the position of the follicle under investigation in the hierarchy of ovarian follicles, and from the position of any eggs in the oviduct, the approximate time at which follicular blood was sampled relative to the expected time of ovulation of the follicle was estimated for each bird.

Plasma was immediately separated by centrifugation and stored at $-20^{\circ} \mathrm{C}$ until assay.

\section{Extraction of oestradiol}

A blood sample $(10 \mathrm{ml})$ was taken from the brachial vein of a laying hen approximately $6 \mathrm{hr}$ before the predicted time of ovulation (estimated from the previous laying record and the presence of a hard-shelled egg in the shell gland) and the bird was immediately killed by cervical dislocation. The largest follicle, the second largest follicle, the third, fourth and fifth follicles, two postovulatory follicles, the rest of the ovary consisting of small $(<5 \mathrm{~mm})$ follicles and stroma, a piece of liver, and a piece of pectoral muscle were quickly dissected out and placed on ice. A distilled water blank was also included. The five large follicles were punctured and the yolk discarded since it does not contain large quantities of oestrogens (Hertelendy \& Common, 1965).

The tissue samples were weighed (Table 2) and then homogenized in 3 vols distilled water using a Silverson homogenizer. The homogenate was added to a flask containing $\left[{ }^{3} \mathrm{H}\right]$ oestradiol- $17 \beta\left(2 \times 10^{5} \mathrm{~d} / \mathrm{min} ; 250 \mathrm{pg}\right)$ and extracted overnight with 10 vols acetone. The precipitate was then removed by filtration 
and was washed with a further two 3-vol aliquots of acetone. The combined filtrate was evaporated to dryness and the weighed and dried extract was submitted to chromatography on silica gel. A slurry in light petroleum (B.P. $60^{\circ}$ to $80^{\circ} \mathrm{C}$ ) of silica gel (British Drug Houses, 60 to $120 \mathrm{mesh}$ ) previously activated at $105^{\circ} \mathrm{C}$ for $10 \mathrm{~min}$ was used to pack a column, $26 \mathrm{~cm} \times 1.5 \mathrm{~cm}$ i.d. The extract was transferred to the column with two 2-ml aliquots of toluene. Elution of the column with toluene removed a large proportion of the lipid; a fraction containing steroids was then eluted with acetone.

The acetone was distilled off and the extract was submitted to chromatography on the strongly basic anion exchange resin Dowex 1 (Sigma Chemical Co.) using a modification of the procedure of Eberlein (1969). A suspension in distilled water of the resin in the bicarbonate form was pipetted into a glass column, $10 \mathrm{~cm}$ long $\times 1 \mathrm{~cm}$ i.d. to a height of $4 \mathrm{~cm}$. The column was equilibrated by passing $30 \mathrm{ml}$ methanol through it. The extract was transferred to the column with two 2-ml aliquots of methanol, and neutral lipids and steroids were eluted with a further $25 \mathrm{ml}$ methanol; phenolic steroids were then eluted with $15 \mathrm{ml}$ of a mixture of $4 \%$ glacial acetic acid in methanol.

The phenolic steroids were subjected to chromatography on a $15-\mathrm{cm}$ column of Sephadex LH-20 with the solvent system toluene:methanol $(85: 15 \mathrm{v} / \mathrm{v})$, as previously described (Senior, 1974a) and a fraction containing oestradiol was obtained. The dried oestradiol fraction was dissolved in $1 \mathrm{ml}$ redistilled toluene and $100 \mu \mathrm{l}$ of the solution were removed. The radioactivity was counted to estimate procedural losses.

\section{Oestradiol assays}

Oestradiol in blood plasma was measured by radioimmunoassay (Senior, 1974b).

The tissue extracts were assayed at several levels, using the same procedure as for plasma.

\section{RESULTS}

\section{Oestradiol in follicular venous blood plasma}

Samples collected from two of the five birds contained barely detectable levels of oestradiol. The remaining three birds provided twenty-six samples of follicular venous blood. Table 1 shows that the concentrations of oestradiol in these samples ranged from 66 to $264 \mathrm{pg} / \mathrm{ml}$ and appeared to be lower than the levels in peripheral blood taken at the same time.

\section{Oestradiol in ovarian tissue}

The mean total content of oestradiol in each tissue examined was calculated from the values obtained at all levels of the extract; the results for each ovarian tissue are also expressed as a percentage of the total ovarian content (Table 2). The highest levels of oestradiol were found in the liver and in the small follicles and ovarian stroma. All tissue levels were significantly higher $(P<0 \cdot 001)$ than the blank value of $134 \mathrm{pg}$.

The oestradiol concentration in the peripheral plasma was $159 \mathrm{pg} / \mathrm{ml}$. 
B. E. Senior and B. J. A. Furr

Table 1. Concentrations of oestradiol in the venous plasma from the ovarian follicles of laying hens

\begin{tabular}{|c|c|c|}
\hline Bird No. & Tissue & Oestradiol $(\mathrm{pg} / \mathrm{ml})$ \\
\hline \multirow[t]{3}{*}{$\mathbf{F} 2$} & Follicle at least $50 \mathrm{hr}$ before ovulation & $\begin{array}{l}145 \\
116 \\
133\end{array}$ \\
\hline & $1 \mu \mathrm{g}$ NIH-LH injected & $\begin{array}{l}\longrightarrow 225 \\
264 \\
183 \\
143 \\
229 \\
194\end{array}$ \\
\hline & Peripheral plasma & 1077 \\
\hline \multirow[t]{2}{*}{ F3 } & Follicle at least $40 \mathrm{hr}$ before ovulation & $\begin{array}{l}180 \\
162 \\
130 \\
174 \\
125 \\
121 \\
191 \\
218\end{array}$ \\
\hline & $\begin{array}{r}\text { Peripheral plasma: } \begin{array}{r}100-\mu 1 \text { aliquot } \\
200-\mu 1 \text { aliquot } \\
300-\mu 1 \text { aliquot }\end{array}\end{array}$ & $\begin{array}{l}315 \\
344 \\
339\end{array}$ \\
\hline F5 & Follicle at least $20 \mathrm{hr}$ before ovulation & $\begin{array}{r}80 \\
96 \\
89 \\
66 \\
157 \\
88 \\
81 \\
174 \\
235\end{array}$ \\
\hline & $\begin{array}{r}\text { Peripheral plasma: } 300-\mu \mathrm{l} \text { aliquot } \\
600-\mu 1 \text { aliquot }\end{array}$ & $\begin{array}{l}211 \\
171\end{array}$ \\
\hline
\end{tabular}

Samples were collected over 10-min intervals and a sample of peripheral blood was also drawn from each bird.

Table 2. The concentration of oestradiol in tissues from a laying hen

\begin{tabular}{|c|c|c|c|c|c|}
\hline \multirow[b]{2}{*}{ Tissue } & \multirow[b]{2}{*}{ Net wt $(g)$} & \multirow{2}{*}{$\begin{array}{c}\text { Recovery of } \\
\text { radioactive tracer } \\
(\%)\end{array}$} & \multicolumn{3}{|c|}{ Oestradiol content $(p g)$} \\
\hline & & & $\begin{array}{c}\text { Whole tissue } \\
(\text { mean } \pm \text { S.E.M. })^{*}\end{array}$ & $\begin{array}{c}\text { Per } \\
g \text { tissue }\end{array}$ & $\begin{array}{c}\% \text { of } \\
\text { ovarian total }\end{array}$ \\
\hline $\begin{array}{l}\mathbf{L} \\
\mathbf{M} \\
\mathrm{F}_{1} \\
\mathbf{F}_{2} \\
\mathbf{F}_{3 / 5} \\
\text { POF } \\
O \\
\text { B }\end{array}$ & $\begin{array}{l}6 \cdot 640 \\
7.241 \\
3.563 \\
1.898 \\
4.867 \\
0.539 \\
3.962 \\
-\end{array}$ & $\begin{array}{l}78 \cdot 1 \\
73 \cdot 2 \\
86 \cdot 9 \\
79 \cdot 9 \\
70 \cdot 8 \\
25 \cdot 3 \\
64 \cdot 4 \\
49 \cdot 5\end{array}$ & $\begin{array}{r}15,930 \pm 348 \\
669 \pm 42 \\
858 \pm 92 \\
1,024 \pm 86 \\
975 \pm 98 \\
2,218 \pm 638 \\
34,405 \pm 662 \\
134 \pm 20\end{array}$ & $\begin{array}{r}2,399 \\
92 \\
241 \\
540 \\
200 \\
4,115 \\
8,936 \\
-\end{array}$ & $\begin{array}{r}- \\
\overline{2 \cdot 1} \\
2 \cdot 5 \\
2 \cdot 4 \\
5 \cdot 5 \\
87 \cdot 5 \\
-\end{array}$ \\
\hline
\end{tabular}

L, liver; $M$, muscle; $F_{1}$, largest ovarian follicle; $F_{2}$, second largest follicle; $F_{3 / 5}$, combined third, fourth and fifth largest follicles; POF, postovulatory follicles; $O$, remainder of ovary (stromal tissue and small follicles $<5 \mathrm{~mm}$ diam.) $B$, distilled water blank.

* Six or ten determinations at three or five levels of each tissue extract. 


\section{DISCUSSION}

The specificity of the assay method for measuring oestradiol in tissues requires some comment since, particularly in the ovary and liver, high concentrations of a large range of steroids are likely to be present. The anion-exchange column separated phenolic from neutral steroids but, in addition, the antiserum bound non-phenolic steroids to an extent which was $<0.01 \%$ of the binding of oestradiol-17 $\beta$. Although oestrone and oestriol were $80 \%$ and $10 \%$, respectively, as effective in binding to the antiserum as oestradiol- $17 \beta$, they were clearly separated from the oestradiol epimers on Sephadex LH-20, as most probably were the oestriol epimers and 16-oxo-oestrone and 16-oxo-oestradiol-17 $\beta$. Of the steroid oestrogens secreted by the hen (Mathur \& Common, 1968), oestradiol- $17 \alpha$ probably contributes to the value measured. We have therefore stated in the results that concentrations of oestradiol, rather than oestradiol-17 $\beta$, are measured.

The concentration of oestradiol in the peripheral plasma of laying hens varies during the ovulatory cycle in a manner congruent with the concept that oestrogens are involved in the mechanism controlling the release of LH required for ovulation (Senior, 1974a; Senior \& Cunningham, 1974). It would seem logical that the signal which informs the hypothalamo-pituitary system that the follicle is ready to ovulate should come from the follicle itself but no net secretion of oestradiol could be detected by maturing follicles 20 to $50 \mathrm{hr}$ before ovulation. Rather, the follicles appeared to be accumulating oestradiol from the peripheral plasma. This agrees with earlier work on the uptake of $\left[{ }^{3} \mathrm{H}\right]$ oestradiol by the follicle wall (Hawkins, Heald \& Taylor, 1969a, b). The very high value found in the peripheral plasma of bird F2 exaggerates the difference between peripheral and follicular vein levels but this may be due to the treatment of this hen with ovine LH. Certainly oestradiol concentration increased twofold in follicular venous blood 20 min after this treatment.

The follicular vein cannulation procedure will have some influence on blood flow through the follicle, but it is not likely that this will significantly affect the steroid output since progesterone was present in high concentrations in the same plasma samples that contained low levels of oestradiol (Furr, 1973). The conclusion that oestradiol is not an important secretion of these large follicles is also supported by the finding that all such follicles together account for only $7.0 \%$ of the total ovarian oestradiol content.

The largest quantity of oestradiol was present in the numerous small $(<5 \mathrm{~mm})$ follicles and ovarian stroma. This conclusion agrees closely with that of earlier work in which Allen, Whittset, Hardy \& Kneibert (1924) and Marlow \& Richert (1940) found that oestrogenic activity, judged by cornification of the vagina of spayed rats, was confined to the small follicles. In the present investigation, no attempt was made to determine whether the follicles or the stroma were responsible for the high levels of oestradiol found. Boucek \& Savard (1970) demonstrated the presence of the enzymes $\Delta^{5}$ - $3 \beta$-hydroxysteroid oxidoreductase and $17 \beta$-hydroxysteroid oxido-reductase in ovarian stromal cells.

All these results indicate that, unlike progesterone (Furr, 1969, 1973), oestradiol is not secreted by the major follicles, at least up to $20 \mathrm{hr}$ before the 
time of ovulation, and that the basal secretion of oestradiol during the hen's ovulatory cycle is probably derived from the small follicles or ovarian stroma (or both). Without undue trauma to the preparation, however, it was not found possible to identify and cannulate follicles at much closer times to ovulation when the peripheral plasma rise in oestradiol level occurs (Senior \& Cunningham, 1974). Certainly, the major follicles contain enzymes necessary for oestrogen biosynthesis (Chieffi \& Botte, 1965; Boucek \& Savard, 1970) and further investigations are essential to determine whether a large increase in oestradiol output by the follicles occurs 4 to $8 \mathrm{hr}$ before ovulation.

\section{AGKNOWLEDGMENT}

We gratefully acknowledge the financial support of the British Egg Marketing Board.

\section{REFERENCES}

Allen, E., Whitset, J. W., Hardy, J. W. \& Knetbert, E. L. (1924) The follicular hormone of the hen ovary. Proc. Soc. exp. Biol. Med. 21, 500-503.

Boucrk, R. J. \& SAvard, K. (1970) Steroid formation by the avian ovary in vitro (Gallus domesticus). Gen. $\mathcal{E}$ compar. Endocr. 15, 6-11.

Chirffi, G. \& Botte, V. (1965) The distribution of some enzymes involved in the steroidogenesis of hen's ovary. Experientia, 21, 16-17.

EberLein, W. R. (1969) The measurement of low levels of oestrone and oestradiol-1 $7 \beta$ in urine, employing ion exchange, thin layer and gas-liquid chromatography. Steroids, 14, 553-573.

Fraps, R. M. (1955) Egg production and fertility in poultry. In Progress in the Physiology of Farm Animals, Vol. 2, pp. 661-680. Ed. J. Hammond. Butterworths, London.

Fraps, R. M. (1961) Ovulation in the domestic fowl. In Control of Ovulation, pp. 133-140. Ed. C. A. Villee. Pergamon Press, Oxford.

FRAPS, R. M. \& DURY, A. (1943) Occurrence of premature ovulation in the domestic fowl following administration of progesterone. Proc. Soc. exp. Biol. Med. 52, 346-349.

FURR, B. J. A. (1969) Identification of steroids in the ovaries and plasma of laying hens and the site of production of progesterone in the ovary. Gen. $\mathcal{E}$ compar. Endocr. 13,506.

FURR, B. J. A. (1973) Radioimmunoassay of progesterone in peripheral plasma of the domestic fowl in various physiological states and in follicular venous plasma. Acta endocr., Copenh. 72, 89-100.

FurR, B. J. A., BonNey, R. C., England, R. J. \& Cunningham, F. J. (1973) Luteinizing hormone and progesterone in peripheral blood during the ovulatory cycle of the hen, Gallus domesticus. $\mathcal{F}$. Endocr. 57, 159-169.

Glencross, R. G., Munro, I. B., Senior, B. E. \& Pope, G. S. (1973) Concentrations of oestradiol-17ק, oestrone and progesterone in jugular venous plasma of cows during the oestrous cycle and in early pregnancy. Acta endocr., Copenh. 73, 374-384.

Hawkins, R. A., HeALd, P.J. \& TAYLOR, R. (1969a) The uptake of $\left[6,7-{ }^{3} \mathrm{H}\right] 17 \beta$-oestradiol by tissues of the domestic fowl. Acta endocr., Copenh. 60, 199-209.

Hawkins, R. A., Heald, P. J. \& TayloR, R. (1969b) The uptake of $\left[6,7-{ }^{3} \mathrm{H}\right] 17 \beta$-oestradiol by tissues of the domestic fowl during an ovulation cycle. Acta endocr., Copenh. 60, 210-215.

Hertelendy, F. \& Common, R. H. (1965) A chromatographic investigation of egg yolk for the presence of steroid estrogens. Poult. Sci. 44, 1205-1209.

Kappaur, B. \& VAn Tienhoven, A. (1972) Progesterone concentrations in peripheral plasma of laying hens in relation to the time of ovulation. Endocrinology, 90, 1350-1355.

Marlow, H. W. \& Rrchert, D. (1940) Estrogens in the fowl. Endocrinology, 26, 531-534.

Mathur, R. S. \& Common, R. H. (1968) Metabolism of steroid estrogens in the hen. II. Conversion in vivo of estradiol-17 $\alpha-4-{ }^{14} \mathrm{C}-17 \beta-{ }^{3} \mathrm{H}$ to $17-e p i e s t r i o l-4-{ }^{14} \mathrm{C}-17 \beta-{ }^{3} \mathrm{H}$. Steroids, 12, 725-734.

Peterson, A. J. \& Common, R. H. (1971) Progesterone concentration in peripheral plasma of laying hens as determined by competitive protein binding assay. Can. 7. Zool. 49, 599-604.

Peterson, A. J. \& Common, R. H. (1972) Estrone and estradiol concentrations in peripheral plasma of laying hens as determined by radioimmunoassay. Can. J. Zool. 50, 395-404.

RALPH, C. L. \& FRAPS, R. M. (1959) Long term effects of diencephalic lesions on the ovary of the hen. Am. F. Physiol. 197, 1279-1283. 
RALPH, C. L. \& FraPs, R. M. (1960) Induction of ovulation in the hen by injection of progesterone into the brain. Endocrinology, 66, 269-272.

SENIOR, B. E (1974a) Changes in the concentrations of oestrone and oestradiol in the peripheral plasma of the domestic hen during the ovulatory cycle. Acta endocr., Copenh. 77, 588-596.

SENIOR, B. E. (1974b) Radioimmunoassay of oestrone and oestradiol in the peripheral plasma of the domestic fowl in various physiological states and of hypophysectomized and ovariectomized fowls. Acta endocr., Copenh. 75, 133-140.

Senior, B. E. \& Cunningham, F. J. (1974) Oestradiol and luteinizing hormone during the ovulatory cycle of the hen. F. Endocr. 60, 201-202.

Vande Wiele, R. L., Bogumil, J., Dyrenfurth, I., Ferin, M., Jewelewicz, R., Warren, M., RizkALLAH, T. \& MrKhaIL, G. (1970) Mechanisms regulating the menstrual cycle in women. Recent Prog. Horm. Res. 26, 63-103. 